\title{
Thermo-erosional notch development at fresh-water-calving Tasman Glacier, New Zealand
}

\author{
Katrin RÖHL \\ Department of Geography, University of Otago, PO Box 56, Dunedin, New Zealand \\ E-mail: katrin_roehl@yahoo.com
}

\begin{abstract}
Controls on glacier calving rates are receiving increased scientific interest. At fresh-watercalving glaciers, limnological factors might be more important than glaciological ones. Measurements of thermo-erosional notch development at the calving ice cliff of Tasman Glacier, New Zealand, suggest that the calving rates at this glacier are directly controlled by the rate of thermal undercutting. Notch formation rates typically vary between 10 and $30 \mathrm{~cm} \mathrm{~d}^{-1}$ (maximum rate $65 \mathrm{~cm} \mathrm{~d}^{-1}$ ) in summer, corresponding to an average calving rate of $34 \mathrm{~m} \mathrm{a}^{-1}$. Notch formation is slower than waterline melt and is controlled by water temperatures and circulation, cliff geometry, debris supply and water-level fluctuations. The latter shift the position of undercutting, resetting the level of the notch formation process and thereby slowing it. The geometry of the notch and the debris supply determine the extent of influence of the lake on notch water temperatures and circulation. Hence, water temperatures in the lake are not necessarily indicative of the rate of notch formation. The prediction of rate of notch formation from far-field variables is hampered by the complex interaction of the influencing factors. The significance of thermal undercutting as a calving rate-controlling process decreases with increasing ice velocities, calving rates and surface gradients.
\end{abstract}

\section{INTRODUCTION}

Wherever ice is in contact with water for a sufficient length of time, ice melt at the waterline causes notches to be formed. This is because melting of ice at the waterline proceeds at a higher rate than either subaqueous or subaerial melting (Josberger, 1978). A horizontal notch cut into an ice face at the waterline will create shear and tensile stresses in the overlying ice, which is likely to lead to failure. For calving glaciers, undercutting of the ice cliff as a possible important process for calving was suggested in the $1960 \mathrm{~s}$ (Goldthwait and others, 1963; Reid and Callender, 1965). Only recently has this process received more attention, and waterline melting associated with thermo-erosional notches has been suggested as a significant control on calving rates at slow-moving glaciers terminating in lakes (Kirkbride and Warren, 1997). Studies of notch development are rare, and have mostly focused on saline water and laboratory experiments (e.g. Martin and others, 1978; Eijpen and others, 2003). So far, data on notch formation rates are scarce (e.g. Benn and others, 2001; Haresign and Warren, 2005) and do not allow the significance of this process for calving rates to be assessed. In this paper, the process of notch development is investigated at an actively calving ice cliff in fresh water. The aim is to quantify rates of thermal undercutting, to identify the controls on this process and to quantify them as far as possible.

A considerable amount of research has investigated possible controls on calving rates, most of them focusing on tidewater glaciers. Among several relationships between calving rates and other glaciological parameters, the correlation between calving rate and water depth is the most widely accepted (e.g. Brown and others, 1982; Funk and Röthlisberger, 1989). Although Hanson and Hooke (2000) suggested the development of flow-induced oversteepening of the ice face as a possible physical explanation, the causality remains somewhat uncertain. Other potential controls on calving rates include the glacier thickness and effective pressure at the glacier bed (Van der Veen, 1996), buoyancy of the terminus (Warren and others, 2001), subaqueous melt (Motyka and others, 2003) and water temperature (Warren and Kirkbride, 2003), the latter being closely connected with the process of thermal undercutting.

Compared with the amount of research addressing the dynamics of tidewater glaciers, little attention has been given to glaciers and calving processes in lacustrine settings. Significant contrasts exist between calving rates and calving mechanisms at these different glacier margins (Warren and others, 1995; Warren and Kirkbride, 2003), so relationships and process explanations derived from tidewater glaciers are not necessarily applicable to fresh-water glaciers. Numerous supraglacial and proglacial lakes have developed in conjunction with 20th-century retreat associated with global warming. An improved understanding of these glacier margins is also valuable for the prediction and management of hazards associated with these types of lakes for hydroelectric power generation, recreational purposes and areas threatened by potential glacier outburst floods. In addition, many of these lakes have formed at glaciers with a supraglacial debris cover which affects ice loss and modifies the supraglacial topography (e.g. Kirkbride, 1989; Benn and others, 2001). Subsequent pond and lake development seems to provide the precursors to terminus disintegration and accelerated retreat. However, little attention has been given to the influence of debris on ice-marginal processes like calving. This study addresses these issues and sets out to test whether thermal undercutting is the controlling process for calving rates at this type of glacier, featuring a supraglacial debris cover and low ice velocities.

\section{SITE DESCRIPTION}

Tasman Glacier, with a length of about $29 \mathrm{~km}$, is the largest glacier in New Zealand, draining the eastern side of the Southern Alps (Fig. 1). Its lower $8 \mathrm{~km}$ are debris-covered and 


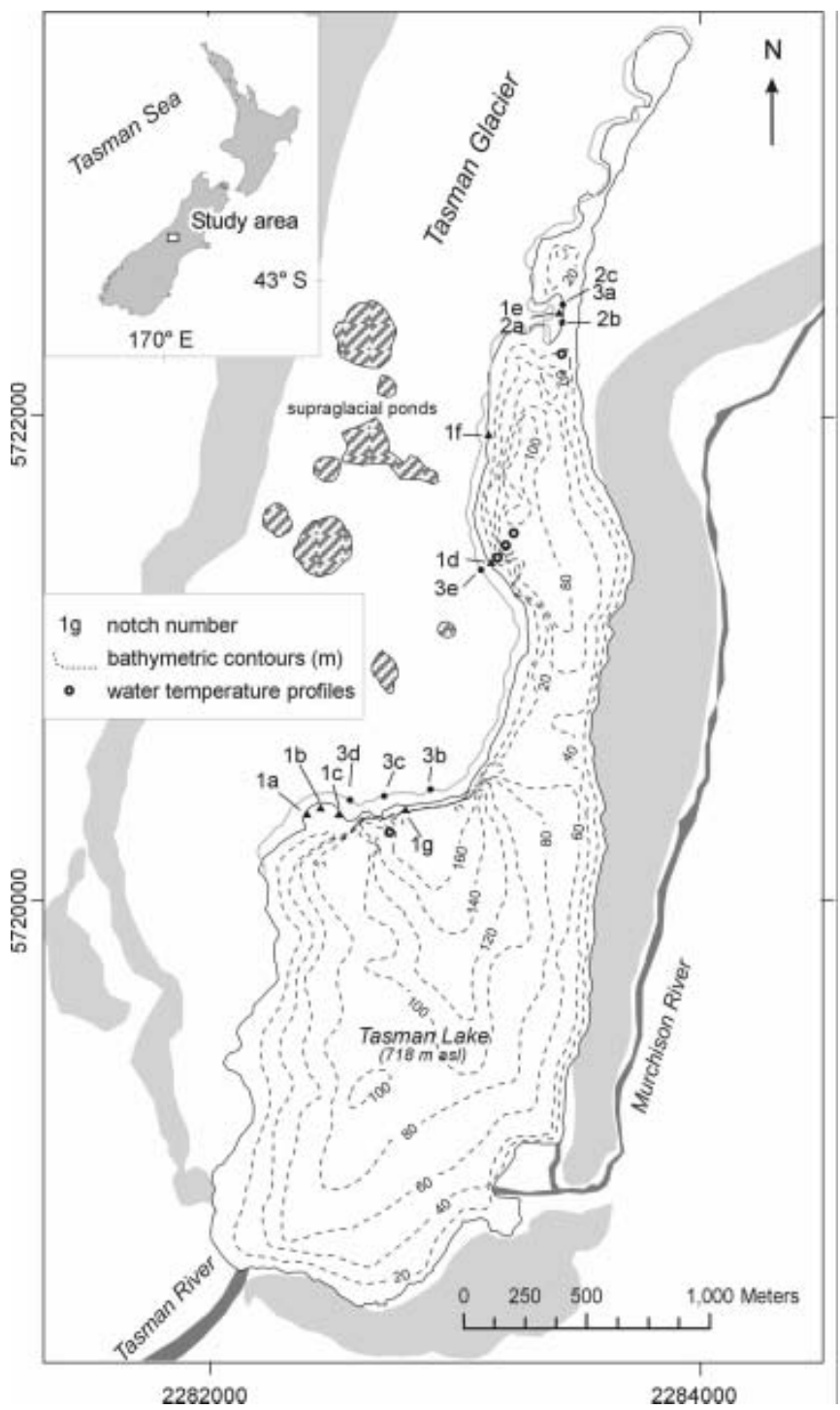

Fig. 1. Location map of Tasman Glacier and Tasman Lake (New Zealand Map Grid). The shaded area indicates moraines, and the notch locations are indicated. Note that several notches (e.g. 1e and 2a) are at the same location.

largely uncrevassed, featuring numerous supraglacial ponds. After decades of downwasting, a proglacial lake formed in the 1980s (Kirkbride, 1993), and calving commenced in the 1990s. A considerable amount of research has been undertaken on the terminus dynamics and lake properties (e.g. Hochstein and others, 1995; Kirkbride and Warren, 1999; Roehl, 2003) revealing a complex interaction between limnological and glaciological processes. Currently, Tasman Lake covers an area of approximately $3.7 \times 10^{6} \mathrm{~m}^{2}$ and has maximum and average water depth along the ice cliff of 180 and $50 \mathrm{~m}$, respectively. Part of the lake floor is still ice-cored, particularly in the northern area where it is shallower (Fig. 1). The subaerial ice cliff is typically 10-15 m high, but varies from a few metres to $35 \mathrm{~m}$ in places. Supraglacial debris of $1 \mathrm{~m}$ average thickness covers the lower few kilometres of the glacier. Notch development occurs wherever ice is exposed to the water, but is suspended for 1-2 months in winter when the lake is frozen.

The regional climate is dominated by westerly airflows from the Tasman Sea. The precipitation is orographically enhanced by the Southern Alps, resulting in high rainfall to

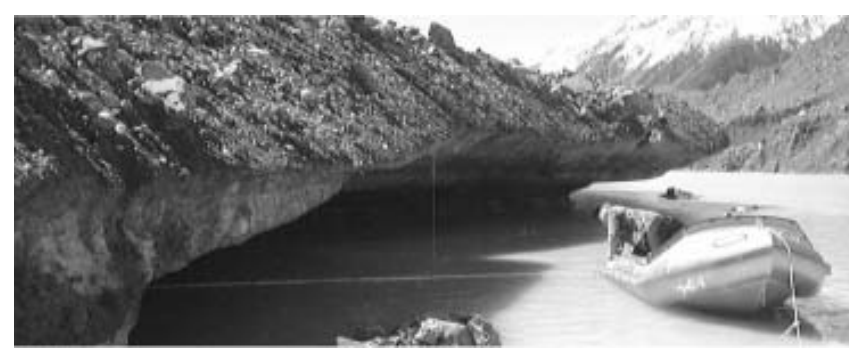

Fig. 2. Method of investigating thermo-erosional notch development shown here at notch 3a. Note the stepped geometry of the notch due to lake-level drop.

the west of the main divide, decreasing significantly towards the east. Tasman Glacier receives about $7000 \mathrm{mma}^{-1}$ of rainfall in its upper reaches (Anderton, 1975), whilst near the terminus area precipitation ranges from about 3000 to $5000 \mathrm{~mm} \mathrm{a}^{-1}$. While warm föhn winds occur frequently in the eastern ranges, the prevailing wind direction is southsouthwest (Hay and Fitzharris, 1988), though it can be very variable in the terminus area.

\section{METHODS}

A total of 17 notches at 14 locations were surveyed over three different time periods between 2001 and 2003 (Table 1). Floating pipes were used to measure the notch depth at specific locations accessed by boat. A weighted rope draped down the ice cliff and left in place between surveys marked the measurement reference location. The marked pipe was oriented perpendicular to the cliff, and two readings were taken, one when the tip reached the rope and the other at the back of the notch (Fig. 2). The difference yielded the depth of the notch. Repeated measurements at each notch indicated uncertainties between \pm 2 and $6 \mathrm{~cm}$, depending on accessibility and notch shape. Water temperature was measured at about $5 \mathrm{~cm}$ water depth at the cliff face and at the back of the notch with a thermocouple (accuracy $\pm 0.1^{\circ} \mathrm{C}$ ) attached to the pipe. Successive measurements over several days defined the evolving geometry of the notches. Measurements at each location usually ceased after 3-6 days because of calving danger at the notch or nearby. The water level was monitored using a pressure transducer throughout surveys 1 and 2, and by conventional surveying at the start and end of each day of fieldwork during survey 3 . Both methods had an accuracy of $\pm 1 \mathrm{~cm}$. Several vertical temperature profiles down to $125 \mathrm{~m}$ depth were obtained in the lake using an electronic temperature sensor with an accuracy of $\pm 0.1^{\circ} \mathrm{C}$.

The investigation and interpretation of notch formation in this way needs to consider the sub-aerial melt of the overlying ice, as the weighted rope as the reference point retreats progressively with backwasting of the ice. This melt rate was obtained from direct measurements at stakes drilled into the ice cliff during surveys 1 and 2, and was estimated for survey 3 on the basis of climatological observations from a climate station $7 \mathrm{~km}$ from the terminus (Table 1 ). The subaerial melt was assumed to be similar at different locations of the same survey, and the cross-sections of the subaerial cliff were assumed to be constant. Annual and seasonal subaerial melt rates from 16 transects on bare ice walls of supraglacial ponds and melt rates derived from ASTER 


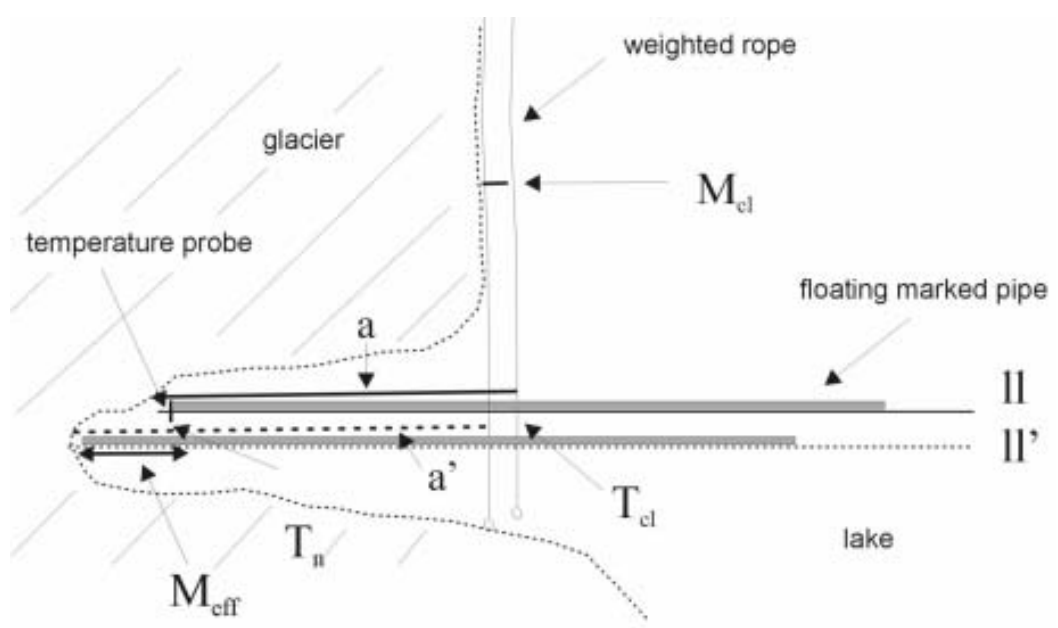

notch depth $\mathbf{a}=$ horizontal distance between rope and back of notch

notch formation rate $=$ difference between $a$ and a' per unit time

melt rate $\mathbf{M}_{n}=$ notch formation rate plus horizontal cliff melt rate $\mathrm{M}_{\mathrm{w}}$

cliff $\mathbf{m e l t}$ rate $\mathbf{M}_{\mathrm{c}}=$ horizontal ice melt at subaerial cliff

effective melt rate $\mathbf{M}_{\mathrm{tn}}=$ horizontal melt rate at the back of the notch based on notch cross section and lake level changes

lake level II = lake-level at time of measurement

$\mathbf{T}_{\mathrm{d}}=$ Surface water temperature at the rope

$\mathbf{T}_{n}=$ Surface water temperature at the back of the notch

Fig. 3. Measurements and terms used in this study.

(Advanced Spaceborne Thermal Emission and Reflection Radiometer) image processing were used as the basis for the melt rate in the calculation of calving rates.

At times when the lake level changed considerably due to precipitation variations and the development of the notch continued at different levels, an 'effective melt rate' was derived from examination of the cross-section and based on the changed lake level (Fig. 3). This rate represents an estimate of the actual horizontal ice melt at the waterline. The cross-section is based on visual observations and direct measurements of the notch above and below the waterline where possible.

Ice velocities and positions of the ice cliff (intervals of 1-12 months) and water temperature profiles were measured using global positioning system (GPS) data with a horizontal accuracy of about $\pm 0.35 \mathrm{~m}$ and vertical accuracy of about $\pm 0.65 \mathrm{~m}$. Retreat rates of the ice cliffs were determined by repeated cliff surveys using three methods: surveying on foot on the top of the cliff, surveying from a boat with an offset from a laser range finder, and using satellite images from ASTER to determine terminus changes over a 3 year period. Accuracy for the methods was $\pm 1, \pm 3$ and $\pm 3.5 \mathrm{~m}$, respectively.

Observations of calving processes and mechanisms were made throughout two summer seasons and several winter field visits using surveying methods and photography. Water depths were mapped with a Hummingbird $200 \mathrm{kHz}$ singlebeam echo sounder. Vertical measurements of water depths had an accuracy of $\pm 1 \mathrm{~m}$ over a range $5-125 \mathrm{~m}$. No practical solution was found to measure water currents in or near the notches.

\section{RESULTS}

\section{Notch formation rates, melt rates and water temperatures}

The rates and forms of notch development differed markedly between surveys and locations. During the first

Table 1. Overview of the investigation of thermal undercutting

\begin{tabular}{|c|c|c|c|c|c|c|}
\hline Survey & Observation period & $\begin{array}{c}\text { Total number of } \\
\text { notches }\end{array}$ & Notch identification & $\begin{array}{l}\text { Number of notches } \\
\text { with useful results }\end{array}$ & $\begin{array}{l}\text { Horizontal cliff } \\
\text { melt rate } \\
\mathrm{cm} \mathrm{d}^{-1}\end{array}$ & $\begin{array}{l}\text { Range of lake level } \\
\text { variation } \\
\mathrm{cm}\end{array}$ \\
\hline 1 & 16 Dec 2001 to 30 Dec 2001 & 8 & $1 \mathrm{a}-1 \mathrm{~h}$ & 5 & 10 & $\begin{array}{c}10 \\
(15 \text { for notch } 1 b)\end{array}$ \\
\hline 2 & 24 Feb 2002 to 08 Mar 2002 & 4 & $2 a-2 d$ & 3 & 7 & 80 \\
\hline 3 & 21 Feb 2003 to 26 Feb 2003 & 5 & $3 a-3 e$ & 5 & 8 & 75 \\
\hline
\end{tabular}




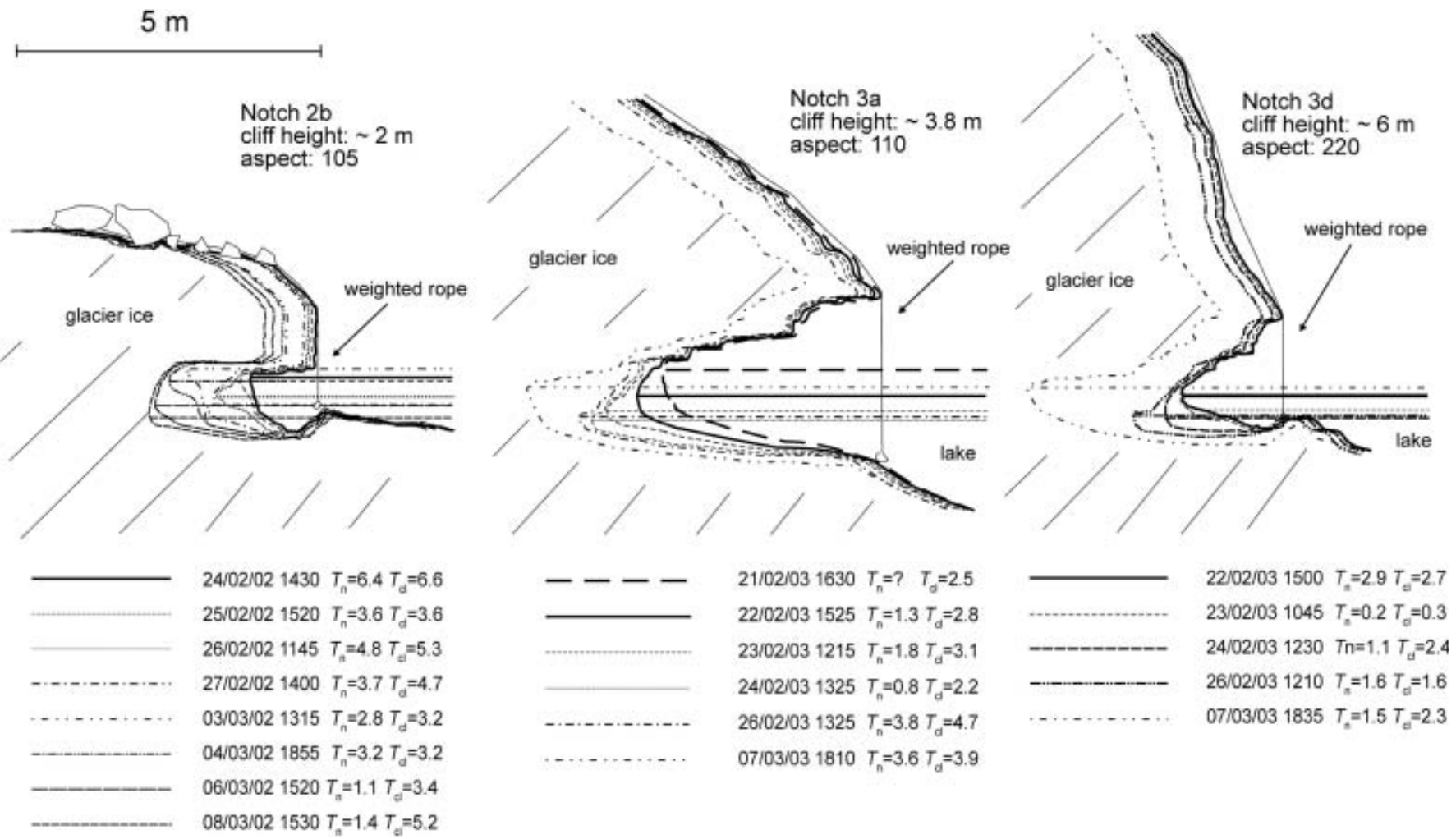

Fig. 4. Cross-sections showing the development of thermo-erosional notches. Dates are $\mathrm{dd} / \mathrm{mm} / \mathrm{yy}$.

survey, the weather was comparatively settled, with the exception of two rain events, resulting in small lake-level variations. Except for notch 1e, the notch areas were not suitable for a detailed investigation of the undercutting geometry, so the effective melt rate could not be determined. During the second and third surveys the weather was variable, with some major rain events, resulting in larger lake-level fluctuations (Table 1). Solar radiation and air temperatures were generally lower than those during the first survey, so cliff melt was lower (Table 1). Notches $2 \mathrm{a}-2 \mathrm{c}$ and $3 \mathrm{a}$ were located on a small peninsula in the north of the lake with low cliffs and shallow subaqueous topography at and near the notches (Figs 1 and 2). This setting restricted water circulation but also reduced the danger of calving events and enabled a more detailed investigation of the geometry of the notches and their evolution.

Notch formation rates typically varied between 10 and $30 \mathrm{~cm} \mathrm{~d}^{-1}$ (maximum rate $65 \mathrm{~cm} \mathrm{~d}^{-1}$ ). However, large waterlevel fluctuations shift the position of undercutting, resetting the level of the notch formation process (Fig. 4), so rates can be effectively negative due to the measurement position at the waterline. The highest rates were accordingly observed in the first survey, which had least lake-level variations (Fig. 5). Effective melt rates at the back of the notch ranged mostly between 15 and $40 \mathrm{~cm} \mathrm{~d}^{-1}$ (maximum rate $75 \mathrm{~cm} \mathrm{~d}^{-1}$ and minimum $5 \mathrm{~cm} \mathrm{~d}^{-1}$ ) but showed substantial spatiotemporal variation (Figs 6 and 7). Water temperatures in

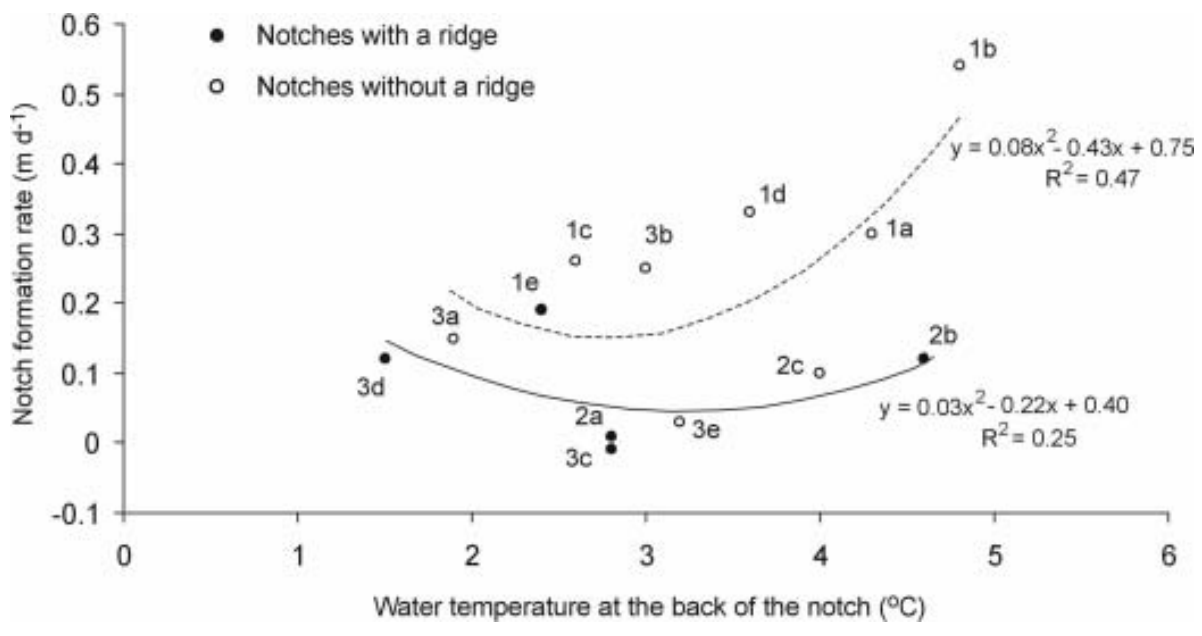

Fig. 5. Average notch formation rates from all surveys over 2-4 day measurement periods plotted against the water temperature at the back of each notch. 


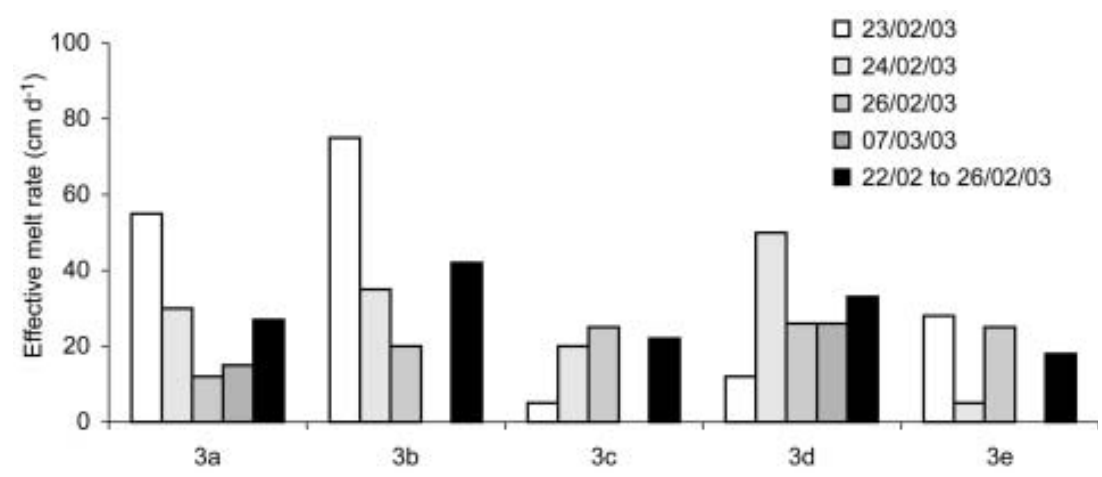

Fig. 6. Temporal variation of effective melt rates at five locations at Tasman Glacier. Dates are $\mathrm{dd} / \mathrm{mm} / \mathrm{yy}$.

the notches also showed high variability between 0.2 and $6.4^{\circ} \mathrm{C}$ (see Fig. 4 for some examples). The temperature gradient from the back of the notch towards the cliff ranged mostly from 0 to $0.7^{\circ} \mathrm{Cm}^{-1}$, with an average of around $0.3^{\circ} \mathrm{Cm}^{-1}$. However, negative gradients also occurred in some instances, caused by specific changes in the crosssection of notches.

Notch growth and changing geometry over time is illustrated for three notches in Figure 4 . After steady growth for 8 days at notch $2 b$, the notch depth effectively decreased as a result of limited water circulation due to a very low lake level and a debris-laden ridge in front of the cliff. This is reflected in the low water temperatures of 1.1 and $1.4^{\circ} \mathrm{C}$. The temporal variability of water temperatures, notch formation and effective melt rate at this notch are illustrated in Figure 7.

The development of notch $3 \mathrm{a}$ is a good example of the influence of both changing geometry and water temperature. The subaqueous topography near the notch was deeper than at notch $2 \mathrm{~b}$ and water circulation less restricted both towards the lake and the sides. This is reflected by an almost constant temperature gradient between the back of the notch and the cliff of around $0.30^{\circ} \mathrm{Cm}^{-1}$. The effective melt rate was relatively high at around $50 \mathrm{~cm} \mathrm{~d}^{-1}$ in the first 3 days, but dropped with the lowering lake level to $12 \mathrm{~cm} \mathrm{~d}^{-1}$. The notch depth was steadily increasing at first but was halted by a large lake-level increase. Water depth a few metres away from notch $3 \mathrm{~d}$ was $17 \mathrm{~m}$, but this notch also showed a debris-laden ridge in front and a clear dependence on water temperature. Initially, the notch formation rate was negative $\left(-24 \mathrm{~cm} \mathrm{~d}^{-1}\right)$ and effective melt rate was low $\left(12 \mathrm{~cm} \mathrm{~d}^{-1}\right)$, which coincided with very low water temperature in the notch $\left(0.3^{\circ} \mathrm{C}\right)$. Subsequently, notch formation and melt rate rose markedly with higher water temperatures (Fig. 4).

\section{Notch shape}

The base of the notch often displays a reverse slope towards the lake (Fig. 4). This is caused by differential melting of the debris-free clean ice within the notch and the debriscovered ice just outside. Where the immediate subaqueous area is shallow, gravel ridges frequently develop as a result of backwasting of the ice cliff and the subsequent fall of debris into the lake. This restrains the water circulation towards the notch and thereby slows notch formation. This is well illustrated by the comparison of rates at notches with
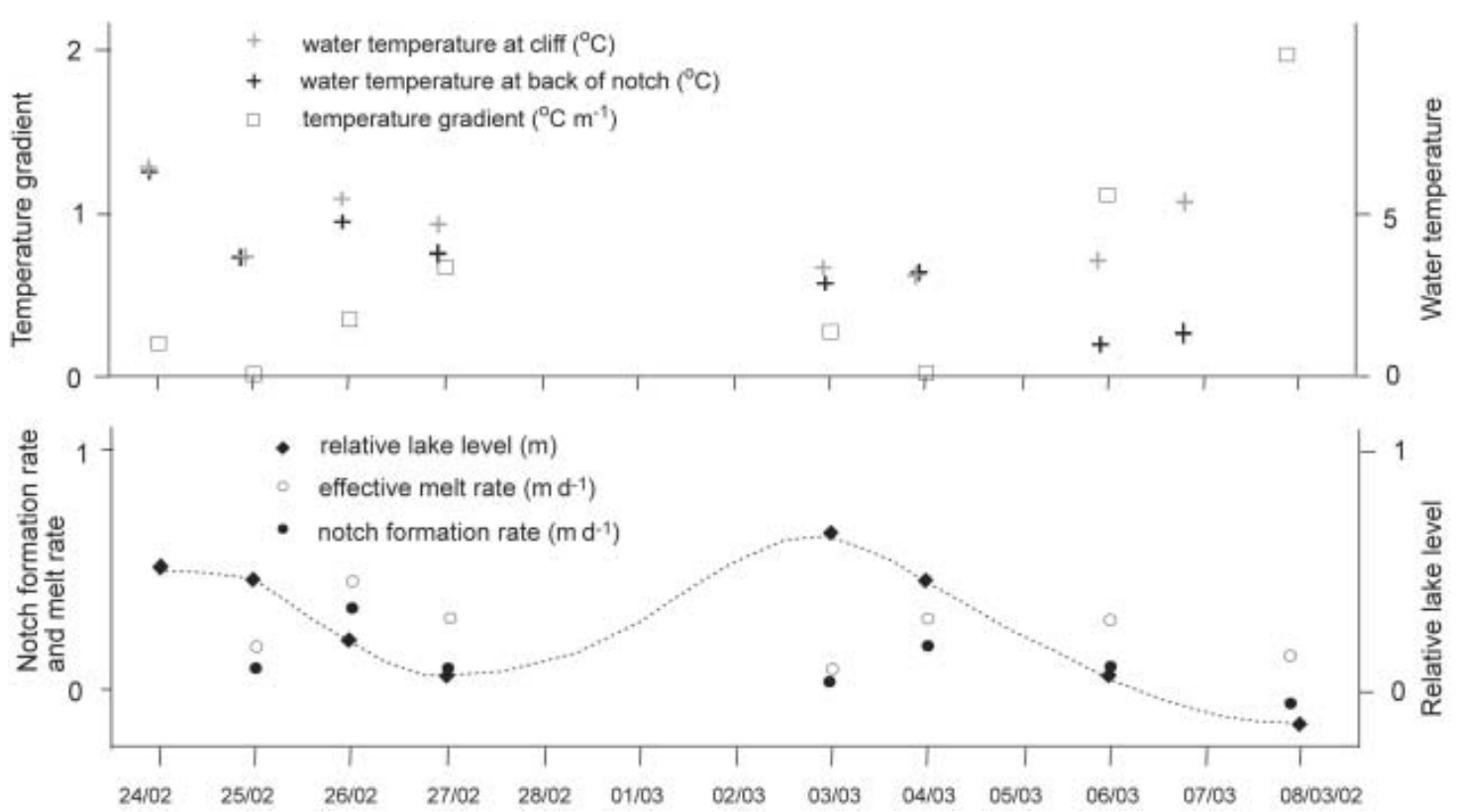

Fig. 7. Temporal variation of notch formation rate, effective melt rate, water level and temperatures at notch $2 \mathrm{~b}$ over 12 days (24 February-8 March 2002). 


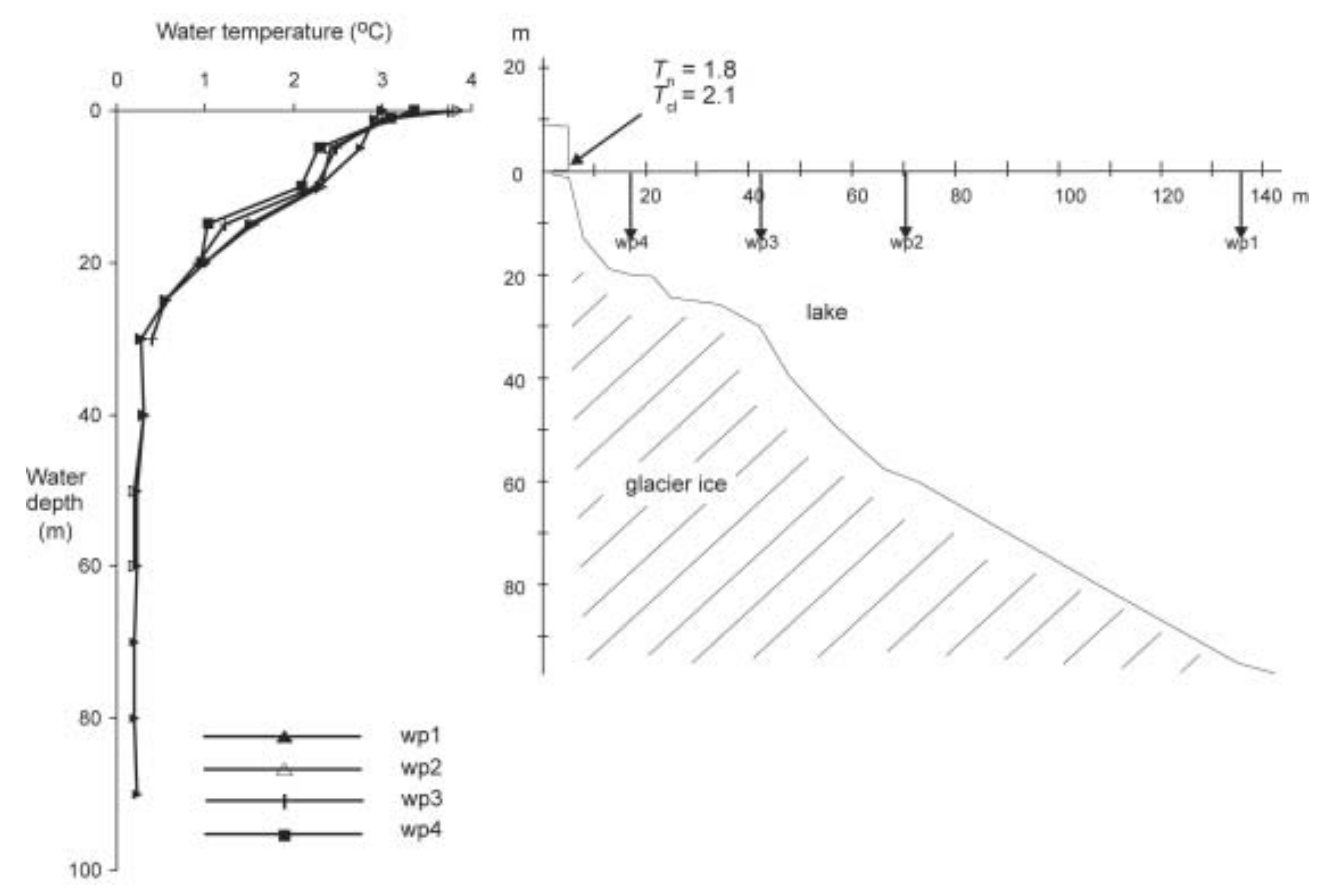

Fig. 8. Subaqueous geometry and water temperature profiles (wp) in the vicinity of notch $1 \mathrm{~d}$ measured on 17 December 2001 between 1100 and $1200 \mathrm{~h}$.

and without ridges (Fig. 5) which show average rates of 0.25 and $0.09 \mathrm{~m} \mathrm{~d}^{-1}$, respectively.

Variations in the depth and shape of the notch between large sections of the ice cliff are determined by calving history, cliff height and location. Their morphometry can range from no notch, or even a gravel-covered ice foot, to deeply undercut sections. The process of thermal undercutting can lead to notches that are up to $\sim 10 \mathrm{~m}$ deep. The deepest notches have been observed along cliff sections with slope angles of around $45-55^{\circ}$. If the notch formation rate is positive, the overlying ice eventually collapses. The ratio of cliff height to notch depth at the time of calving varies typically between 1.5 and 2, with cliff heights from 10 to $20 \mathrm{~m}$ showing maximum notch depths between 5 and $10 \mathrm{~m}$. No calving events have been observed without prior undercutting of the ice face.

Variations within certain cliff sections are caused by lateral variations in the shape and height of the cliff and available debris. The development of a 'gravel foot' can temporarily inhibit any form of undercutting at that point, leading to a crescent-shaped notch in plan view. On the smaller scale of several metres, the backs of the notches often show undulations of about $0.5-1 \mathrm{~m}$ within $5 \mathrm{~m}$ laterally, as observed, for example, at notch $1 \mathrm{~b}$. In addition to irregular holes and shapes caused by the melt-out of debris, cusps are often observed. These give the ice surface a pock-marked appearance, with indentations of $\sim 1 \mathrm{~cm}$ diameter, similar to those described by Martin and others (1978) in laboratory experiments.

The vertical scale of the notch is estimated to be 0.20 $0.30 \mathrm{~m}$, provided the water level stays constant. The upper and lower surfaces are not parallel but tend to converge at variable angles as evident in Figure 4. Lake-level variations cause the location of waterline melt to shift considerably, thereby widening the notch vertically. In addition, radiation reflection at the water surface may contribute to enhanced melt at the upper surface of the notch. These processes can lead to a vertical extent of the notch at the front of up to $2.5 \mathrm{~m}$ (see the examples in Fig. 4).

\section{Limnological observations}

During survey 1 , lake water temperature in the vicinity of the notches showed little variation between locations and on different days. Temperatures ranged from 3 to $10^{\circ} \mathrm{C}$ at the surface and dropped to under $1^{\circ} \mathrm{C}$ below $40 \mathrm{~m}$. Figure 8 shows a typical example for this survey. Water temperature profiles taken at various distances from notch $1 \mathrm{~d}$ reveal a decrease in temperature at water depths from 5 to $15 \mathrm{~m}$ of around $0.5^{\circ} \mathrm{C}$ towards the ice cliff (Fig. 8). Surface temperatures in the lake were higher than at the ice cliff and at the back of the notch, where temperatures are lowered by ice melt and warming of the surface layer by solar radiation is restricted due to shading. During survey 2, temperature profiles near the notch area show surface temperatures of around $3^{\circ} \mathrm{C}$, decreasing rapidly to about $1^{\circ} \mathrm{C}$ at $10 \mathrm{~m}$ depth. At the notches water temperatures were higher at times (e.g. notch $2 \mathrm{~b}$ (Figs 4 and 7 )), which may be due to the shallow water in the immediate vicinity.

In contrast to survey 1 , a thermal stratification of the water body, which differed markedly between locations and changed with time, was present during survey 3 (Fig. 9). The variations of effective melt rates at the notches during the same time largely do not correspond to temperature variations in the lake (represented by a low $R^{2}$ of 0.01 for all data shown in Fig. 10). However, the correlation is stronger for some notches at certain times than others (e.g. notch 3 a with an $R^{2}$ of 0.69 ).

Surface currents and waves were very variable and largely followed the pattern of wind, the direction and speed of which changed on a diurnal basis and was influenced by local relief. A comparison between melt rates and averaged wind speed does not indicate any dependence. Though no 

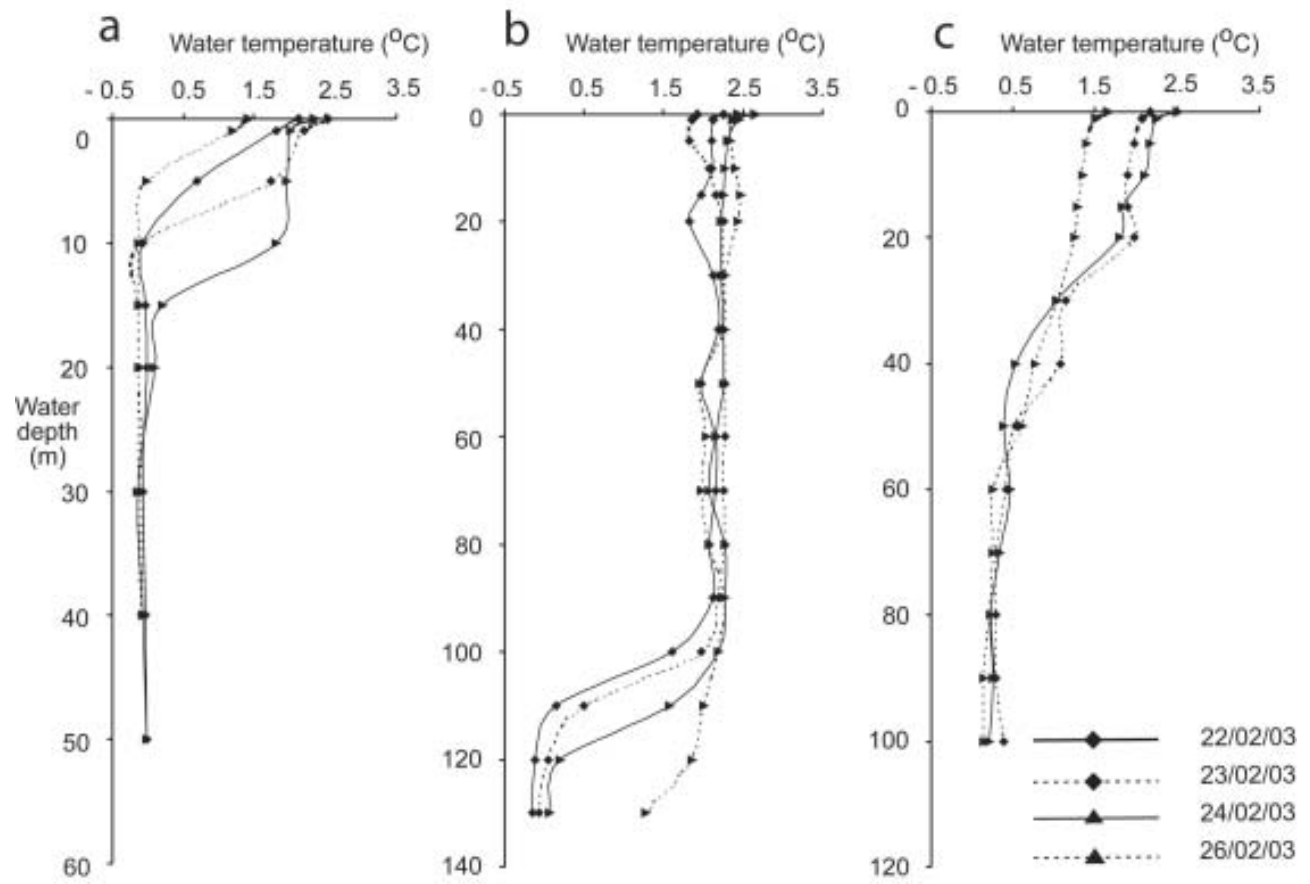

Fig. 9. Vertical water temperature profiles from several days in the notch areas (dates are $\mathrm{dd} / \mathrm{mm} / \mathrm{yy}$ ). (a) Notch $3 a$, (b) notch $3 c$ and (c) notch 3e. Time of measurement was between 1230 and $1430 \mathrm{~h}$ on all days.

current measurements could be made, observations near the ice face indicate localized horizontal currents up to about $0.2 \mathrm{~m} \mathrm{~s}^{-1}$. However, investigations at the ice cliff were restricted to calm weather, so observations are specific to these conditions. Wave heights are estimated to reach amplitudes of up to $\sim 0.2 \mathrm{~m}$ on an irregular basis.

\section{Glaciological parameters}

Calving rates, $v_{\mathrm{C}}$, can be calculated using

$$
v_{\mathrm{c}}=v_{\mathrm{i}}-v_{\mathrm{t}}-v_{\mathrm{m}},
$$

where $v_{\mathrm{i}}$ is the ice velocity, $v_{\mathrm{t}}$ the change in terminus position and $v_{\mathrm{m}}$ ice melt at the calving face. All parameters are width-averaged. The calving face of Tasman Glacier shows an irregular shape (Fig. 1), and ice velocity and retreat rates show some spatial variation. Annual ice velocity along the terminal face ranged between 2 and $8.5 \mathrm{ma}^{-1}$, with the predominant direction of flow to the southeast. The change in terminus position ranged between 30 and $75 \mathrm{~m} \mathrm{a}^{-1}$, and cliff retreat by subaerial melt averaged $22 \mathrm{ma}^{-1}$.

For the lower cliff (between locations $1 \mathrm{a}$ and $1 \mathrm{~d}$ ) average annual ice velocity was $2.5 \mathrm{~m} \mathrm{a}^{-1}$ and cliff retreat was $\sim 60 \mathrm{~m} \mathrm{a}^{-1}$, yielding an average calving rate of $40.5 \mathrm{~m} \mathrm{a}^{-1}$. Seasonal differences are pronounced, with calving rates of $\sim 30 \mathrm{~m} \mathrm{a}^{-1}$ in winter and up to $80 \mathrm{ma}^{-1}$ in summer. The maximum annual calving rate was observed in the southwestern area at $\sim 73 \mathrm{ma}^{-1}$, and the lowest occurred in the northern area (between $1 \mathrm{e}$ and $1 \mathrm{f}$ ) at $16 \mathrm{ma}^{-1}$, yielding an average calving rate for the whole ice cliff of $\sim 34 \mathrm{~m} \mathrm{a}^{-1}$.

\section{DISCUSSION}

\section{Controls on thermo-erosional notch development}

The process of undercutting of an ice cliff is driven by melt at the waterline. However, the effectiveness of this undercutting in terms of mechanically weakening the ice to the point of calving depends on the rate of melt and the location of melt. The field data show that variation in water level dominantly controls this effectiveness, with high notch formation rates coinciding with small lake-level variations. Due to the necessity of distinguishing between waterline melt and notch formation rate (or change in notch depth), an effective melt rate was introduced as a useful way of expressing the speed of ice melt at the waterline. This effective melt rate can be compared to laboratory experiments and theoretical calculations of ice melt, whereas the notch formation rate is the actual speed at which an ice cliff is undercut, eventually leading to calving.

The results show that undercutting of the ice cliff is most effective when the water level stays relatively constant, which is only temporarily the case, as large fluctuations are common in this type of glacial setting. On the basis of the

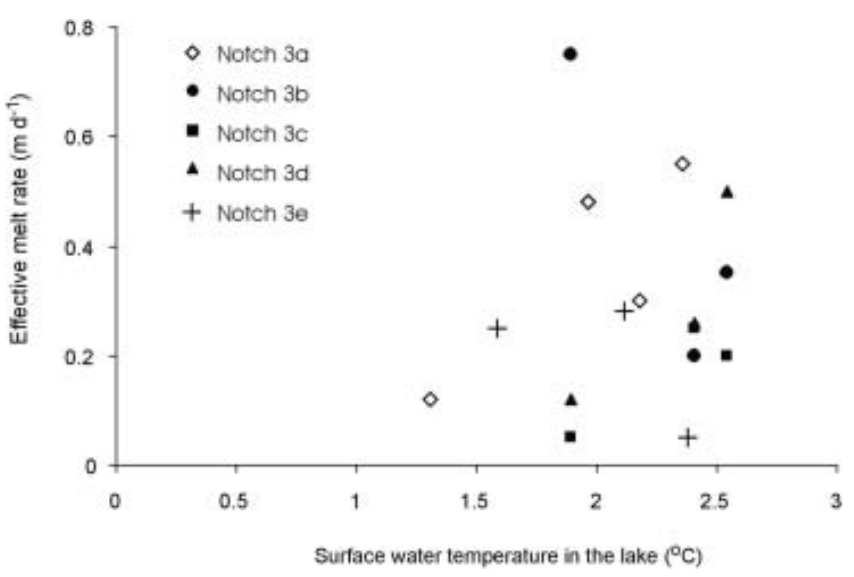

Fig. 10. Effective melt rates plotted against the water temperatures in the upper $1 \mathrm{~m}$ of the lake in the vicinity of the notches during four days in survey 3 . 
Table 2. Coefficients of correlation between water temperatures, gradient and notch depth with notch formation rates of survey 1 and effective melt rates of surveys 2 and 3

\section{Frontal ridge exists?}

Number of data points
Notch depth

$$
\mathrm{m}
$$

Water temperature at back of notch
Water temperature Temperature gradient at cliff

${ }^{\circ} \mathrm{C}$

${ }^{\circ} \mathrm{C}$

${ }^{\circ} \mathrm{Cm}^{-1}$

\begin{tabular}{lcrrrr}
\hline Notch 1a-1e & only at 1e & 5 & 0.70 & 0.72 & 0.13 \\
Notch 2a and 2b & yes & 11 & 0.19 & 0.34 & 0.27 \\
Notch 2c & no & 7 & -0.45 & 0.65 & 0.88 \\
Notch 3a, 3b and 3e & no & 11 & -0.06 & -0.35 & -0.09 \\
Notch 3c and 3d & yes & 7 & 0.37 & -0.24 & -0.17 \\
\end{tabular}

formation rates and cross-sections from all surveys, it is estimated that a water-level rise or drop of more than about $15 \mathrm{~cm}$ within 24 hours reduces notch formation significantly, depending on the pre-existing cross-profile. Shallow water and particularly debris-laden ridges in front of the notch contribute to this reduction, while at the same time the height of the cavity increases (Figs 4 and 5).

The rate of ice melt at the waterline is determined by conductive and convective heat transfer. It is obvious, though, that the melt rates reported here cannot be caused primarily by conduction but that advective heat transfer must play a predominate role. Water with a temperature gradient of $0.3^{\circ} \mathrm{C} \mathrm{m}^{-1}$ could conduct about $0.2 \mathrm{~W} \mathrm{~m}^{-2}$, while a melt rate of $20 \mathrm{~cm} \mathrm{~d}^{-1}$ requires around $700 \mathrm{~W} \mathrm{~m}^{-2}$. However, water temperature is likely to be an important control on notch formation, which could explain the positive correlation between water temperature and calving rate reported by Warren and Kirkbride (2003). The present data show that the relationship between water temperature and notch formation rate is not straightforward, and correlation results differ markedly between locations and surveys (Table 2). Because of the different conditions during the three surveys, in particular in terms of water-level variations and notch locations, and the significant difference in notch formation rates at notches with and without a frontal ridge, the respective datasets are considered separately. A clear relationship is not evident. For example, a positive correlation exists between notch formation rate and temperature at the back of the notch, temperature gradient and notch depth for survey 1 ; and between effective melt rate and water temperature at the back of the cliff, for ridge-free notch 2c. However, for other notches correlations are weaker or even reversed (Table 2).

A negative correlation between notch depth and melt or formation rate might be expected due to decreasing heat transfer with increasing depth, but the data do not substantiate this effect. Water temperature at the back of the notch does not depend on the notch depth, but rather on its cross-profile. The importance of local subaqueous geometry and notch geometry is also supported by repeated measurements at the same location. Notches 3a and 2c, measured about 1 year apart, show average notch formation rates of 0.15 and $0.10 \mathrm{md}^{-1}$, respectively, and a close similarity of their cross-sections. These values are close compared to the range of all notch data.

The observation that a simple relationship between melt rate and water temperature is not generally applicable is in accordance with experimental results of Eijpen and others (2003). Convection in their experiments was free, but certain circulation patterns developed that affected subaqueous melting. Even in their small-scale laboratory experiment, complex circulation patterns at the waterline resulted in large variations of melt rates.

There are several reasons for the lack of consistently strong correlation of notch formation and melt rates with water temperature. Water movement towards and within the notch is likely to be a major control on waterline melt. Currents are controlled by the limnological conditions in the vicinity of the notch and the geometry of the notch. Data from all three surveys show that restricted circulation caused by a ridge in front of the notch, shallow lake topography or decreasing water levels (or all of these) affect melt and notch formation rates significantly. In this respect the existence of a debris cover affects processes in the notch too, as it influences both water circulation and water temperature. Besides water circulation, windgenerated wave action is also likely to affect waterline melt to some extent (e.g. Martin and others, 1978). This, however, could not be confirmed for this glacial setting with the present data. Attempts to correlate melt rates with water temperatures are also hampered by the short-term nature of the measurements. Water temperatures can only be taken at the time of notch measurement and thus do not represent values over the time of their formation. Clearer correlation might be obtained from continuous water temperature measurements which would reflect the accumulated effect of turbulent heat transfer between notch depth measurements.

With respect to the influence of water temperature, another important question is how water temperatures within the notches relate to those further away in the lake. Again, no clear relationship emerges. The fact that variations of effective melt rates at the notches did not reflect temperature variations in the lake consistently (Fig. 10) indicates that other factors, such as lake-level changes, local water circulation and the cross-sectional shape, overprint this relationship. Additionally, the complex thermal regime of the lake raises the question of the depth at which the water temperature should be measured for investigating the relationship to undercutting. One could argue that surface temperatures are the most relevant since the majority of heat transport of progressive waves occurs near the surface (Martin and others, 1978). However, relatively high surface temperatures are associated with calm conditions which reduce heat transfer to the ice cliff by surface currents and waves (Roehl, 2003). It is therefore somewhat surprising that a positive correlation was found by Warren and Kirkbride (2003) between calving rates and water temperatures which 
were obtained from short-term measurements of iceproximal water temperatures at $10 \mathrm{~m}$ depth.

In summary, the results indicate that, besides the key variables of water temperature and circulation, the notch formation process is significantly affected by cliff geometry, debris supply and water-level fluctuations, with the notch geometry playing a central role. All these effects are intrinsically linked, giving rise to difficulties in correlating any particular variable to rates of thermal undercutting. The same applies to the influence of wave action, which is likely to affect notch development. However, no direct relationship becomes apparent from this study. The feedback between notch geometry, ice melt, water circulation and temperature has been identified as an important process, in particular in conjunction with debris accumulation and lake-level variations.

\section{Relationship between thermal undercutting and calving}

Based on the present notch formation data, entire ice-cliff geometry, average water temperatures and lake-level variations, an average notch formation rate of $15 \mathrm{~cm} \mathrm{~d}^{-1}$ can be estimated for the summer season. Using this rate, an average cliff height of $12 \mathrm{~m}$ and a ratio of cliff height to notch depth of 1.8, calving events at a particular site in summer can be expected to occur about every 6-7 weeks. This is supported by observations of calving events throughout the summer season which occurred at intervals of 4-8 weeks. Only calving events affecting the full height of the overlying ice face were included. At any particular time, however, the variable nature of the notches and the environmental conditions are likely to lead to variations between cliff sections. On an annual basis, the average calving rate of about $34 \mathrm{ma}^{-1}$ corresponds to a notch formation rate of $9 \mathrm{~cm} \mathrm{~d}^{-1}$. Excluding two months in winter when the lake is frozen, the average rate would be $11 \mathrm{~cm} \mathrm{~d}^{-1}$. This is a reasonable annual rate given the data from 13 notches and suggests that subaerial calving is directly controlled by, and is a result of, thermal undercutting of the ice face. The form, frequency and magnitude of calving events depend on preexisting weaknesses in the glacier ice such as debris bands and crevasses.

Local differences in annual calving rates along Tasman ice cliff may be explained in terms of the controls on notch formation. While the temporal variation is likely to be largely affected by water temperature, the spatial variation is determined to a greater degree by different exposure to currents and waves. For example, accumulation of calved ice in the northern part of the lake in conjunction with generally lower water temperatures caused by floating ice and meltwater inflow is likely to counteract the effect of more rapid local water currents which would otherwise promote ice-cliff retreat following thermal undercutting. In contrast, the relatively high calving rates in the southwestern area may be explained by enhanced undercutting due to higher water temperatures and exposure to wind and waves.

While undercutting rates at Tasman Glacier suggest a direct control on calving rates, neighbouring Hooker Glacier may be just above the threshold of solely thermal undercutting-controlled calving rates. Here, thermo-erosional notches require a development rate of about $0.26 \mathrm{~m} \mathrm{~d}^{-1}$ to account for the cliff retreat by calving at a rate of $79 \mathrm{~m} \mathrm{a}^{-1}$ over a 3 year period. Considering the lake and cliff geometry, and water temperatures and convection in Hooker Lake (unpublished data), it is unlikely that notch formation would proceed at substantially higher rates than at Tasman Glacier. On one hand, waterline melt may be more effective as lakelevel variations are lower; on the other hand, water temperatures are lower and water movement is more restricted given the orientation and smaller size of the lake, so less heat is advected to the ice face. Higher ice velocities, of around $30 \mathrm{~m} \mathrm{a}^{-1}$, and the steeper surface gradient of $3.2^{\circ}$ for Hooker Glacier contribute to more pronounced crevassing at a larger scale. With the addition of the higher ice face, it appears that glacio-dynamic factors are of greater significance than aquatic ones. Differences in calving rates from different observation periods (unpublished data) may be attributed to phases of more or less intense crevassing. The reason for these phases lies, probably, in mass-balance fluctuations, indicating a sensitivity of the terminus to climatic forcing which is typical for lake-calving glaciers (Warren and Kirkbride, 2003). It is interesting to note, though, that both glaciers exhibit much lower calving rates than would be expected from the empirical relationships between calving rate and water depth (e.g. Funk and Röthlisberger, 1989; Warren and Kirkbride, 2003), which supports the concept of undercutting-controlled calving.

The process of thermal undercutting is likely to play a central role in the transition from solely melting to calving termini. This transition has been identified as important in the later stages of lake formation and for the sequence and rate of deglaciation of valley glaciers in New Zealand (Kirkbride, 1993). Evidence from Tasman Glacier (unpublished data) suggests that the connection of ponds or joining of a pond with the lake increases water temperature and currents over a threshold. This results in progressive undercutting of the ice cliff, where waterline melting is greater than subaerial melt, and eventually leads to calving. The secondary control on this transition is sufficiently deep nearshore water. Shallow water leads to an increase in ice and debris accumulation which can lead to termination of calving. Therefore, the onset of subaqueous calving and increasing water depth may be a necessary precursor for the onset of subaerial calving.

\section{Comparison with other notch observations}

Few data exist that would enable comparison between different glaciers or settings. Compared to previously published rates of thermal undercutting at lake-calving glaciers, the rates presented here are relatively small. Undercutting was estimated to be 3-4 $\mathrm{m}$ within a few days at Maud Glacier, New Zealand, with lake water surface temperatures between 3.8 and $4.4^{\circ} \mathrm{C}$ (Warren and Kirkbride, 1998), and rates of $80 \mathrm{~cm} \mathrm{~d}^{-1}$ were observed at fast-calving Glaciar León, Patagonia, with water temperatures of $4.5-8^{\circ} \mathrm{C}$ (Haresign and Warren, 2005). However, comparison is difficult, as these data are either estimates or short-term measurements at only one location. The results presented here show substantial spatio-temporal variation, which needs to be taken into account when assessing the significance of the undercutting process for calving.

Waterline melt at a supraglacial pond on Ngozumpa Glacier, Nepal, was $50 \mathrm{~cm} \mathrm{~d}^{-1}$ based on a 4 hour measurement in October (Benn and others, 2001). However, no water temperatures are given, and it remains unclear if this rate represents melt rate or notch formation rate, as distinguished in this study. It is interesting to note, though, that the position and geometry of weaknesses in the ice 
appeared to be more important than waterline melting, and retreat by calving occurred faster than the rate of thermal undercutting (Benn and others, 2001). An explanation of this might be that weaknesses in the ice play an important role locally and temporarily, but that thermal undercutting is the prevalent controlling factor on calving rates in the long term. At the polar tidewater glacier Hansbreen, Spitsbergen, Vieli and others (2002) estimated a waterline melt rate of $1 \mathrm{~m} \mathrm{~d}^{-1}$, based on a water temperature of $2^{\circ} \mathrm{C}$, a wave height of $0.1 \mathrm{~m}$ and a wave period of $1.5 \mathrm{~s}$. This was in the range of the observed summer calving rates. The reasons for this higher value might lie in the specific differences between these glaciers. Firstly, the effects of waves and water currents might be greater in the polar tidewater environment. In proglacial lakes prolonged periods of wave and current impact are rare, and their intensity and location is very variable. Secondly, the irregular cliff shape and distribution of supraglacial debris on Tasman Glacier lead to interruption or delay of notch formation temporarily, which results in varying rates of undercutting and an overall lower rate.

In contrast, rates from ice-melt experiments in fresh water are significantly lower than those from this field study. Eijpen and others (2003) documented melt rates at the waterline of about 2, 3.5 and $5.5 \mathrm{~cm} \mathrm{~d}^{-1}$ for temperatures of 2,3 and $4{ }^{\circ} \mathrm{C}$, respectively. However, melting in the experiments was concentrated just below the waterline where the melt rate was about $24 \mathrm{~cm} \mathrm{~d}^{-1}$ at $4{ }^{\circ} \mathrm{C}$, which compares well with average effective melt rates of $15-40 \mathrm{~cm} \mathrm{~d}^{-1}$, measured at Tasman Glacier. The low experimental melt rate, and even ice accretion at the waterline, might be caused by the low ice temperature of $-15^{\circ} \mathrm{C}$ at the start of each experiment and the low ambient temperature of the cold laboratory.

The wide range of notch formation rates highlights the complexity of this process. Laboratory experiments can give an indication of melt rates at the waterline and their relation to water temperature and movement. However, the process of undercutting at a calving glacier is controlled by additional factors such as debris supply, level fluctuations and cliff shape. While results from this study do not offer a definite relationship between limnological or glaciological parameters and notch formation rate, they emphasize the effect of the main controls and signify the importance of this process for ice loss at slow-moving glaciers.

\section{CONCLUSIONS}

Investigation of the process of thermal undercutting needs to distinguish between ice melt at the waterline, on the one hand, and notch formation on the other, with the latter eventually leading to calving. An effective melt rate is introduced which considers the change in lake level, and is a useful way of expressing the speed of waterline melting. Notch formation is slower than waterline melt and is controlled by water temperature and circulation, cliff geometry, debris supply and water-level fluctuation. Hence, water temperatures in the lake are not necessarily indicative of the rate of notch formation. The prediction of the rate of notch formation from far-field variables, such as water temperature in the lake, is hampered by the complex interaction of the influencing factors. Current measurements at or within notches would improve the understanding of the notch formation process. However, given the important local influences of debris, water level and notch shape, water movement as a far-field variable is unlikely to be utilized generally as a representative parameter for undercutting rates. The results suggest that the calving rates at Tasman Glacier are directly controlled by the rate of thermal undercutting. The significance of this process for any lakecalving glacier is largely determined by glaciological factors (ice velocity and surface gradient) and limnological factors (water temperature and currents).

\section{ACKNOWLEDGEMENTS}

I am grateful to W. Anderson and R. Bach who risked their necks with me. Support from the Department of Geography is gratefully acknowledged. This paper has benefited from the comments of $\mathrm{H}$. Rott, D. Benn and an anonymous referee.

\section{REFERENCES}

Anderton, P.W. 1975. Tasman Glacier 1971-73. Hydrological Research, Annual Report. 33. Wellington, New Zealand, Ministry of Works and Development for the National Water and Soil Conservation Organisation.

Benn, D.I., S. Wiseman and K.A. Hands. 2001. Growth and drainage of supraglacial lakes on the debris-mantled Ngozumpa Glacier, Khumbu Himal, Nepal. J. Glaciol., 47(159), 626-638.

Brown, C.S., M.F. Meier and A. Post. 1982. Calving speed of Alaska tidewater glaciers, with application to Columbia Glacier. USGS Prof. Pap. 1258-C.

Eijpen, K.J., C.R. Warren and D.I. Benn. 2003. Subaqueous melt rates at calving termini: a laboratory approach. Ann. Glaciol., 36, 179-183.

Funk, M. and H. Röthlisberger. 1989. Forecasting the effects of a planned reservoir which will partially flood the tongue of Unteraargletscher in Switzerland. Ann. Glaciol., 13, 76-81.

Goldthwait, R.P., I.C. McKellar and C. Cronk. 1963. Fluctuations of Crillon Glacier system, southeast Alaska. IASH Bull., 8(1), $62-74$.

Hanson, B. and R.Leb. Hooke. 2000. Glacier calving: a numerical model of forces in the calving-speed/water-depth relation. J. Glaciol., 46(153), 188-196.

Haresign, E. and C.R. Warren. 2005. Melt rates at calving termini: a study at Glaciar León, Chilean Patagonia. In Harris, C. and J.B. Murton, eds. Cryospheric systems: glaciers and permafrost. London, Geological Society of London, 99-109. (GSL Special Publication 242.)

Hay, J.E. and B.B. Fitzharris. 1988. The synoptic climatology of ablation on a New Zealand glacier. J. of Climatol. 8, 201-215.

Hochstein, M.P., D. Claridge, S.A. Henrys, A. Pyne, D.C. Nobes and S.F. Leary. 1995. Downwasting of the Tasman Glacier (South Island, N.Z.): changes in the terminus region between 1971 and 1993. NZ J. Geol. Geophys., 38(1), 1-16.

Josberger, E.G. 1978. A laboratory and field study of iceberg deterioration. In Husseiny, A.A., ed. Iceberg utilization. New York, Pergamon Press, 245-264.

Kirkbride, M.P. 1989. The influence of sediment budget on geomorphic activity of the Tasman Glacier, Mount Cook National Park, New Zealand. (PhD thesis, University of Canterbury.)

Kirkbride, M.P. 1993. The temporal significance of transitions from melting to calving termini at glaciers in the central Southern Alps of New Zealand. The Holocene, 3(3), 232-240.

Kirkbride, M.P. and C.R. Warren. 1997. Calving processes at a grounded ice cliff. Ann. Glaciol., 24, 116-121.

Kirkbride, M.P. and C.R. Warren. 1999. Tasman Glacier, New Zealand: 20th-century thinning and predicted calving retreat. Global Planet. Change, 22(1-4), 11-28. 
Martin, S., E. Josberg and P. Kaufmann. 1978. Wave-induced heat transfer to an iceberg. In Husseiny, $\mathrm{AA}$, ed. Iceberg utilization. New York, Pergamon Press, 260-263.

Motyka, R.J., L. Hunter, K.A. Echelmeyer and C. Connor. 2003. Submarine melting at the terminus of a temperate tidewater glacier, LeConte Glacier, Alaska, USA. Ann. Glaciol., 36, 57-65.

Reid, J.R. and E. Callender. 1965. Origin of debris-covered icebergs and mode of flow of ice into 'Miller Lake', Martin River Glacier, Alaska. J. Glaciol., 5(40), 497-503.

Roehl, K. 2003. Thermal regime of an ice-contact lake and its implication for glacier retreat. In Squire, V.A. and P.J. Langhorne, eds. Ice in the Environment. Proceedings of the 16th IAHR International Symposium on Ice. Volume 1. Dunedin, International Asociation for Hydraulic Research, 304-312.

Van der Veen, C.J. 1996. Tidewater calving. J. Glaciol., 42(141), 375-385.
Vieli, A., J. Jania and L. Kolondra. 2002. The retreat of a tidewater glacier: observations and model calculations on Hansbreen, Spitsbergen. J. Glaciol., 48(163), 592-600.

Warren, C.R. and M.P. Kirkbride. 1998. Temperature and bathymetry of ice-contact lakes in Mount Cook National Park, New Zealand. NZ J. Geol. Geophys., 41(2), 133-143.

Warren, C.R. and M.P. Kirkbride. 2003. Calving speed and climatic sensitivity of New Zealand lake-calving glaciers. Ann. Glaciol., 36, 173-178.

Warren, C.R., D.R. Greene and N.F. Glasser. 1995. Glaciar Upsala, Patagonia: rapid calving retreat in fresh water. Ann. Glaciol., 21, 311-316.

Warren, C., D. Benn, V. Winchester and S. Harrison. 2001. Buoyancy-driven lacustrine calving, Glaciar Nef, Chilean Patagonia. J. Glaciol., 47(156), 135-146.

MS received 24 February 2005 and accepted in revised form 8 February 2006 